\title{
The Alternative Model of CSR in Indonesian Islamic Banking By The ISO 26000 Standard
}

\author{
Khoirul Hidayah \\ Syariah Business Law Departement, Maulana Malik Ibrahim State Islamic University of Malang
}

\begin{abstract}
In Indonesian regulation, CSR is ruled in article 74, law number 40 of 2007 concerning Limited Liability Company. Obligation of CSR just for company in environmental sector or have impact in environmental. It is just focus in environmentally sustainable. The law number 40 of 2007 does not give the obligation of CSR to Islamic Banking as a company in financial sector. There are 3 issues in this paper: The CSR concept (ISO 26000 standard) in Islamic Law perspective, the regulation of CSR in the law number 21 of 2008 concerning Banking and the alternative model of CSR in Islamic banking as company in financial sector. The result of the analyzis: the CSR concept in ISO in 26000 standard is according to the Islamic law, the law number 21 of 2008 does not rule about obligation of CSR. The alternative models CSR for Islamic Banking in Indonesia, the first is the obligation of qardh hasan as CSR can ruled in the law number 21 of 2008 concerning Syariah Banking. Thus, it to be socially responsible and become support micro enterprises. The second is Islamic Banking can analysis in submission credit. The Islamic bank will not accepted the company submission of credit which effect enviromental damages.
\end{abstract}

Keywords - Corporate Social Responsibility, Islamic banking, micro enterprises, qardh hasan

\section{INTRODUCTION}

The beginning of Corporate Social Responsibility concept is released by Howard R. Bowen in 1953 [1]. Bowel define the CSR that the obligations of businessman to pursue those policies, to make those decisions, or to follow those lines of action which are desirable in term of the objectives and values of our society. He said it to his idea in Social Responsibilities of The Businessman. Carroll said that Bowel is Father's corporate social reponsibility'. His Social Responsibility concept means that businessman make policies to charity and philanthropy [2]. Now, there are some association that make definition about CSR like OECD (The Organization for Economic Cooperation and Development). OECD make a definition, the CSR is business's contribution to sustainable development and that corporate behavior must not only ensure return to shareholders, wages to employees, and products and services to consumers, but they must respond to societal and environmental concerns and value. The sustainable is mean development that meet the needs of the present without compromising the ability of future generation to meet their own needs [3]. The terminology of CSR is familiar with social responsibility to stakeholders. Based on some concept about CSR, it means that a company's business model should be socially responsible and environmentally sustainable. CSR commitment of business to minimize its negative impacts and maximize its positive contributions to all stakeholders in connections in economic, social and environmental aspects to achieve sustainable development.

Now, CSR concept made by meetings of working group social responsibility (2005-2010) in draft of ISO 26000 standard. There are 7 issues in ISO 26000: organizational governance, human rights, the labour practices, the environmental, fair operating practices, consumers issues, and development of the community and society [4]. It is a brilliant vision and a good concept in globalization era.

In Indonesia, government regulate CSR in law. CSR is ruled in article 74, law number 40 of 2007 concerning Limited Liability Company, article 15 law number 25 of 2007 and government regulating number 47 of 2012. CSR concept in Indonesia regulation is different with CSR concept in ISO 26000. It is focus in environmentally sustainable, but not in socially responsible. Obligation of CSR just for company in environmental sector or have impact in environmental. The law number 40 of 2007 can interpreted that some companies have not obligation of CSR, the example like Islamic banking which company in financal sector.

In Islamic economy, one of the goals of Islamic banking is to increase the economic growth towards a welfare, a better and just society. CSR concept in the west, it is ethics, like in the concept of ISO 26000. Yasir Yusuf and Zakaria (ISDEF, 2011) said that CSR programs based on Islamic values is ethics too. He made criteria and Islamic instrument of corporate social responsibility towards the creation of a sustainable economic development. The some criteria are namely: shari'ah compliance, equality, responsibility in work, the guarantee of welfare, the guarantee environmental sustainability and charity for preservation of virtue [5].

The law number 21 of 2008 concerning Syariah Banking is one of Islamic economy regulation in Indonesia. It regulate the principles of Islamic Banking, the varians of syariah contract and the varians of 
business in Islamic banking. The law number 40 of 2007 can interpreted that some companies have not obligation of CSR, the example like Islamic banking. Islamic Banking is part of important funding which can develop micro enterprises.This paper will be analize CSR regulation in the law number 21 of 2008 concerning Syariah Banking. The first issue, How the CSR concept (ISO 26000) in the syariah perspective? Secondly, does the law number 21 of 2008 concerning Syariah Banking regulate the CSR? Thirdly, What is the alternative model of CSR in Islamic Banking?

\section{THE CSR REGULATION IN INDONESIA}

This article give explanation that CSR is the obligation in all of the investors. It's mean that all of the companies (domestic investors and foreign investors) shall have obligation in CSR. I have interprete which the terminology of 'company' (in article 74, law number 40 of 2007) is the same with the terminology of 'investor' (in article 15, law number 25 of 2007). Company means a legal entity in capital joint by agreement to do business and the capital split in saham with the regulation (article 1). "Investor" means an individual or a business entity that makes an investment, who may be a domestic investor and a foreign investor (article 1). The regulation about CSR are inconsistence. How about the individual as investor in the law number 25 of 2007 that have obligation to implement the CSR?Its unfair, because the regulation just limited the companies in environmental sector or have impact in enviromental. The regulation are not regulate specially in individual business and business entity form, except the Limited Liability Company.

The CSR is related with sustainable development. Sustainable development explain in article 1 (3) the law number 32 of 2009 concerning Protection and Managemant of Environment. The CSR concept in the Indonesia regulation is not complete and unclear, it make multiintepreted in business actors. The regulation does not give a punishment for the infraction of CSR implementation. It is make difficult to implementation the CSR

\section{CSR CONCEPT (ISO 26000) IN ISLAMIC LAW PERSPECTIVE}

CSR definition according to the World Business Council for Sustainable Development (1999) [6]: The continuing commitment by business to behave ethically and contribute to economic development while improving the quality of life of the workforce and their families as well as of the local community and society at large. This organization have the priority of the CSR activity. They are human rights, employee rights, environmental protection, supplier relation, community involvement, stakeholder rights, CSR performance monitoring and assessment. The European Communities (1993) give definition about CSR in The Green Paper document. The CSR is essentially a concept whereby companies decide voluntarily to contribute to a better society and a cleaner environment. They split the CSR activity in the 2 category [3]: the first, internal aspect of CSR is cover healty, natural resources and human resources management, safety work. Second, external aspect of CSR include empowerment of local community, global environment issue, and human rights.

The Organization for Economic Cooperation and Development (OECD) make definition (2000) [3]:

Business's contribution to sustainable development and that corporate behavior must not only ensure return to shareholders, wages to employees, and products and services to consumers, but they must respond to societal and environmental concerns and value. The sustainable is mean development that meet the needs of the present without compromising the ability of future generation to meet meet their own needs'.

Carroll said that CSR concept: economic responsibility, law, ethics and charity. Acoording him, CSR is described to be pyramid, where the economic responsibility is the key to corporate responsibility, followed by a responsibility to the laws, ethics and the last is charity [7]. Based on the variants of some definitions, it can be concluded that CSR commitment of business to minimize its negative impacts and maximize its positive contributions to all stakeholders in connections in economic, social and environmental aspects to achieve sustainable development.

ISO 26000 is the standard which describe the CSR completely and to be guidelines in international standard. Describtion about the CSR concept in syariah perspective, to make easier and clearly understanding it universally, this paper will made comparative between ISO 26000 principle and Islamic principles in the al Qur'an and hadits.

While in social welfare, Islam encourages highly Islamic charity to those in need and less ability in work through sadaqah (In Islam, the word has two meanings sadaqah. Sadaqah first significant donation to charity, and required that both voluntary donations as charitable contributions) and welfare loans (Qardh hasan). Qardh Hasan is good credit who do not take advantage. Total amount of loan repayments in accordance with the loaned property. Allah said in al Qur'an:

"So fear Allah as much as we can; listen and obey and spend in charity for the benefit of your own soul and those saved from the covetousness of their own souls, they are the ones that achieve prosperity" (QS. al Taghabun, 64: 16). 
These are the CSR principles (ISO 26000) in the Syariah:

\begin{tabular}{lll} 
No & ISO 26000 Concept & \multicolumn{1}{c}{ Islamic Law } \\
\hline $\mathbf{1}$ & $\begin{array}{l}\text { Organizational } \\
\text { governance }\end{array}$ & $\begin{array}{l}\text { To make a decision must considered a justice and cause not carnal } \\
\text { desire. The decision making must have a good impact to all of } \\
\text { stakehoulders (QS. as shad 38: 26). }\end{array}$ \\
\hline $\mathbf{2}$ & Fair operating practices & $\begin{array}{l}\text { Prohibition to foul play (QS. al anfal 8:58). } \\
\text { Prohibition to deceitfully act (QS. al muthaffifin 83: 1). }\end{array}$ \\
\hline $\mathbf{3}$ & Human rights & $\begin{array}{l}\text { Obligation to respect the human (muslim and non muslim). Charity to } \\
\text { all of the people, priority to poor community (QS. an Nisa'4: 36) }\end{array}$ \\
\hline $\mathbf{4}$ & Labour practices & $\begin{array}{l}\text { Islam is very respect to worker. Rasululloh said that the worker wages } \\
\text { must given accordingly his jobs. Wages must given after the jobs is }\end{array}$ \\
& finish and not give wages less. Rasululloh said in hadist: "From \\
& $\begin{array}{l}\text { Abdullah bin Umar, Rasulullah SAW said: "Give the wages to the } \\
\text { worker before his perspiration is dry" (HR. Ibnu Majah dan Imam } \\
\text { Thabrani). }\end{array}$ \\
\hline $\mathbf{5}$ & The environment & $\begin{array}{l}\text { Prohibition in destroying the environmentally (QS. Al-Ruum 30:41 } \\
\text { dan Al Baqarah: 164) }\end{array}$ \\
\hline $\mathbf{6}$ & Consumer issues & $\begin{array}{l}\text { To be trustworty man to all of the people and respect to consumen by } \\
\text { savety and healthy product (QS. al anfal ayat 8: 27). }\end{array}$ \\
\hline & Community involvement & $\begin{array}{l}\text { Minimize a poverty and make prosperity contribution to minority } \\
\text { groups (QS. al Hasyr 59: 7). }\end{array}$
\end{tabular}

Based on the comparation CSR concept in the syariah, so the CSR in the ISO is according to the Islamic principles. Charity and phylantropy in the CSR concept must be done for the muslim (individual and organizations). The implementation of CSR doesn't voluntary, but it's the mandatory for muslim. Platanova has argumentation that The Islamic perspectives on CSR and justice as an alternative to the Western theoretical constructs of CSR. It presents the socially responsible vision and objectives of Islamic Moral Economy with the recourse to the objectives of the Islamic law and an integration of moral filter to the practices of Islamic Banking [8]. The CSR in ISO 26000 standart has the same vision and principle with the moral economy in Islamic law.

\section{THE ALTERNATIVE MODEL OF CSR IN INDONESIAN ISLAMIC BANKING}

Based on the discription about the concept of CSR (ISO 26000) above, the conclution is according to the Islamic principles. This paper will analyze the CSR provision in the Law Number 21 of 2008 about syariah banking. The CSR provision is syariah banking is unclear. The similar activity of CSR in the Law Number 21 of 2008 can see in article 4(paragraph 2-4). The article mention about social function for the Islamic banking. It just one of business syariah banking. CSR in social function is not obligation or mandatory, it is voluntary. If we see in al Qur'an and hadist, social fuction is just not a charity, but its more. Based on describtion before, al Qur'an said that its obligation for all of the human to do charity in social community and environmentally. In Islam law, charity in social function is also called zakah. In kontemporer fiqih and in the law of Zakah says that the organizations like corporation is a subject of zakah (muzaki). In Islam law, the CSR can do by zakah.

In the Indonesian Law number 40 of 2007 concerning Limited Liability Company, the CSR concept is not universally and it just address for the company which effect in environmentally. For the future, the social fuction provision is to be obligation in the law number 21 of 2008. It will to be CSR implementation for the Islamic banking. In the future, Islamic banking must be to be leader/the first promoter of company in CSR implementation. It is unwise, if the law of syariah banking put the CSR/social function as one of business activity.

Because the Indonesia CSR concept is unclear and inconsistence, so the law of syariah banking is better adobting the ISO 26000. It is to easier and make the syariah banking can competitive in globalization and to be missionary endeevour for non muslim. Poverty has been one of the major economic issues in Indonesia for decades. Perhaps not only in Indonesia, as one of the developing countries in the world, but also in other developing countries as well. CSR in one of the models to help the minority group like poor community. There are many models to implement the CSR. In social responsibility, Islam have a specially model to help a minority group like micro enterprises. Its call a qardh hasan. It can help poor community.

Qardh hasan is an interest-free zero return loan scheme that provides the beneficiaries the opportunity to utilize the funds as a means to help expand their micro enterprises, thus enabling them to gain more income, and to help improve their state of welfare [9]. The al Qur'an describes the responsibility of muslim to help 
others through charitable contributions, donations and stinginess is abomination in Islam. The benevolent loan (qardh hasan) described in the al Qur'an, Surah al Baqarah, 2: 245. In the law number 21 of 2008 is mention about qardh in article 1. Qardh in the article is mean a qardh hasan. It is one of financing product in syariah banking (Islamic Banking). It is a kind of credit with free interest and a special model of Islam economics. Althought qardh hasan is mentioned in the law, but as long as there aren't syariah banking product use qardh hasan in practice. In the future, obligation of qardh hasan as CSR can regulated by the law. Thus, it to be socially responsibility and become support micro enterprises.

In Islamic banks in Bangladesh do follow the mandatory forms of CSR. The banks who invest more in CSR activities, will has good reputation and image in society and can successfully attract more customers for their deposit and loan products. It has impact that increasing sell of deposit and investment products, profit of the banks will also increase [10]. In Indonesia, implementing qardh hasan will be prospecting model in Islamic banking. Based on Bangladesh, it model will be increasing reputation and sell of their product.

Qardh hasan is one of the CSR practices in Islamic banking. It is according to the Islamic banking as financial company sector. The business of Islamic banking is intermediate organization between capital community and company (business actor). Therefore the Islamic banking must have contribution to micro enterprises as its stakehoulders. So its better if qardh hasan to be CSR implementation models in Indonesia and to increase the micro enterprises participation in modern market. In ISO 26000 standart, qardh hasan is part of Community involvement and development. Beside that, Islamic banking have participation and contributing to alleviate the poverty in Indonesia. Realization of the qardh hasan as obligation in the law of syariah banking will be the first law promotor to implement the CSR in Indonesia. It's a charity and a part of ibadah to muslim.

In environmentally sustainable, Islamic Banking can analysis in submission credit. The Islamic bank will not accepted the company submission of credit which effect enviromental damages. Alloh command to us to always protect the enviroment to sustainability in living organisms in the world. It is said in Al-Quran Surah Al baqoroh (164) and Surah al A'raf (56). Althought the Islamic Banking is in financial sector, but it can participate in enviromentally sustainable. If it can do by Islamic banking, I think it can to be models in financial sector of company in Indonesia.

\section{CONCLUSION}

The CSR concept in the ISO 26000 are cover Organizational governance, human rights, labour practices, the environment, fair operating practices, consumer issues, community involvement and development. Based on the comparation CSR concept in the syariah, so the CSR in the ISO 26000 is according to the Islamic principles. Charity and phylantropy in the CSR concept must be done for the muslim (individual and organizations). The article 4 the law number 21 of 2008 mention about social function for the syariah banking. It just one of business Islamic banking. CSR in social function is not mandatory, it is voluntary. For the future, because the CSR is according to the Islamic principles, so the social fuction provision is to be obligation in the law number 21 of 2008. It will to be CSR regulation for the Islamic banking. Because the CSR concept in Indonesia regulation is unclear and inconsistence, so its better the CSR concept in Islamic banking can adopting the ISO 26000 principles. In social responsibility, Islam have a specially model to help a minority group like micro enterprises. Its call a qardh hasan. It can help poor community. Qardh hasan is one of models CSR practices in Islamic banking. Its to be socially responsibility and become support micro enterprises. In the future, the obligation of qardh hasan as CSR implementation can regulated in the law of syariah banking. It will help governance goals to be welfare state. In environment responsibility, the Islamic Banking can analysis in submission credit. The Islamic bank will not accepted the company submission of credit which effect enviromental damages.

\section{REFERENCES}

[1] Archie B. Carroll, Corporate Social Responsibility, Business and Society (Chicago, 1999).

[2] Steiner and Steiner George A., Business Government and Society: A Managerial Perspective (Seventh Edition, McGrawHill.International Edition, 1994).

[3] Dwi Kartini, Corporate Social Responsibility (Bandung: Rafika Aditama, 2009).

[4] https://www.iso.org/obp/ui/\#iso:std:iso:26000: ed-1:v1:en

[5] Muhammad Yasir Yusuf \& Zakaria bin Bahari. Islamic Corporate Social Responsibility in Islamic Banking; Towards Poverty Alleviation. Proc. 8th International Conf. on Islamic Economics and Finance (ISDEF), Doha, Qatar, 2011, 19-21.

[6] World Business Council for Sustainable Development. The Busisnes case for Sustainable Development (WBCSD, Geneva, 2001)

[7] Carroll, A. Corporate Social Responsibility: Evolution of Definition Construct, Business and Society, 38 (3), 1999, 264-268.

[8] Spring and Fall, Corporate Social Responsibility from an Islamic Moral Economy Perspective: A Literature Survey, Elena Platonova, Afro Eurasian Studies, 2, 2013, 272-297.

[9] Obaidullah, M., Introduction to Islamic Microfinance. International Institute of Islamic Business and Finance, (IBF Education and Charitable Trust: India, 2008).

[10] Quazi Sagota Samina, Practice of Corporate Social Responsibility in Islamic Banks of Bangladesh, World Journal of Social Sciences, 2 (6), 2012, 1-13. 